\title{
ARTÍCULOS
}

\section{LA DRAMATIZACIÓN DE UNA CIUDAD. SIGNIFICACIONES RITUALES URBANAS DE LA SEMANA SANTA DE HUELVA}

\section{THE DRAMATIZATION OF A CITY. URBAN RITUAL SIGNIFICATIONS IN HUELVA'S SEMANA SANTA}

\author{
José Carlos Mancha Castro ${ }^{1}$
}

Universidad Pablo de Olavide

Recibido: 27 de junio de 2018; Aprobado: 25 de marzo de 2019

Cómo citar este artículo / Citation: Mancha Castro, José Carlos. 2020. "La dramatización de una ciudad. Significaciones rituales urbanas de la Semana Santa de Huelva». Disparidades. Revista de Antropología 75(1): e013. doi: <https://doi.org/10.3989/ dra.2020.013>.

RESUMEN: Este artículo es una mirada sobre la Semana Santa de Huelva a partir de uno de sus significados más profundos como fiesta religiosa popular: la imagen de un drama ritual urbano en el que se expresan diferentes discursos y narrativas, donde se ritualiza la relación de los sujetos participantes y los grupos sociales entre sí, con el lugar habitado y con las instancias de poder político y religioso. Englobado en una investigación etnográfica de mayor amplitud, centramos aquí la mirada en uno de los diferentes significados productores de sentido para la comprensión de esta compleja fiesta religiosa popular. Analizamos la conformación, estructura y temporalidad del drama ritual y proponemos una interpretación acerca del simbolismo contenido en los cortejos procesionales que se ponen en juego en el ceremonial público.

PALABRAS CLAVE: Ritual; Fiesta; Religiosidad popular; Simbolismo; Semana Santa; Huelva.

ABSTRACT: This paper is an approach to Huelva's Semana Santa based on one of its deepest meanings as a popular religious festival: the image of an urban ritual drama in which different discourses and narratives are expressed, where participants and social groups ritualize their relationship to one another, with the inhabited space, and with the political and religious authorities. Part of a more extensive ethnographic study, here we focus our attention on one of the different sense-producing meanings to help understand this complex popular religious fiesta. We analyse the formation, structure and temporality of the ritual drama and also suggest an interpretation of the symbolism contained in the processions that comes into play in this public ceremonial tradition.

KEYWORDS: Ritual; Performance; Popular Religiosity; Symbolism; Semana Santa; Huelva.

Copyright: (C) 2020 CSIC. Este es un artículo de acceso abierto distribuido bajo los términos de la licencia de uso y distribución Creative Commons Reconocimiento 4.0 Internacional (CC BY 4.0).

1 Correo electrónico: jose.mancha@pi.uhu.es. ORCID iD: <https://orcid.org/0000-0003-0092-4417>. 


\section{INTRODUCCIÓN}

A la altura de los años veinte del siglo pasado, el escritor costumbrista Luis Martínez Kleiser (2003 [1924]: 10-11) decía:

En la Semana Santa [...] contemplamos, simultáneamente, distinción, fervor, cultura, ignorancia, desbordamiento y hasta liviandad; porque integran el piadoso festejo el pueblo y la nobleza, la materia y el espíritu, el recogimiento y la orgía, confundidos y mezclados.

En esa sinopsis literaria, estaba señalando su manifiesto carácter híbrido, su compleja naturaleza social y simbólica y las múltiples maneras de ver y entender la fiesta. A lo largo de su historia, la denominada Semana Mayor nunca ha podido ser explicada desde una única perspectiva; jamás ha podido ser entendida como un hecho social y simbólico unisignificativo, aunque ese haya sido el anhelo y el objetivo de los diferentes poderes económico-políticos y religiosos que han pretendido bien controlarla, bien aniquilarla. A través de ella, han lanzado multitud de símbolos, mensajes y memorias; han intentado reflejar los diferentes imaginarios ideológicos hegemónicos de cada período histórico; y, también a través de ella, quienes no han comulgado con esos poderes, han combatido esa visión impuesta, la han negado en el plano simbólico y han resignificado los diferentes símbolos deslizados por el complejo ritual. «De ahí que el fenómeno de la Semana Santa sea aparentemente inexplicable» (Martínez Velasco 2013: 114).

El estudio de fiestas y rituales como lenguajes proyectivos de una realidad social, como espacios sociosimbólicos por los que transitan ideas, mensajes y símbolos memorialísticos y como instrumentos utilizados por los diferentes poderes para legitimar un determinado modelo social e ideológico unitario, sin quiebras (Moreno Navarro 1999 [1974]: 59; Domene Verdú 2017), es uno de los temas clásicos en antropología social. Desde el inicio de la disciplina, «los rituales han sido tema de interés constante en el que descubrir incesantemente relieves desapercibidos o insuficientemente captados» (García García 1991: 9). Si nos sumergimos en la vasta literatura antropológica, comprobamos que se trata de una temática que ha producido ríos de tinta y que continúa estando de actualidad, ya que los rituales «siguen constituyendo manifestaciones especialmente significativas para analizar nuestros modelos de sociedad» (Agudo Torrico y Jiménez de Madariaga 2011: 1757). Desde los trabajos clásicos hasta las actuales investigaciones historiográficas y etnográficas, que se aproximan a la construcción simbólica de regímenes políticos que basan su legitimidad en un aura de sacralidad utilizando los rituales religiosos populares ${ }^{2}$, se trata de un objeto de estudio ampliamente abordado.

Diferentes autores clásicos se aproximaron a la comprensión de los rituales entendiéndolos como procesos sociales y simbólicos, como ejercicios de metacomunicación (Geertz 2003 [1973]), intentando descifrar y explicar su funcionamiento, estructura y plasticidad, y moviéndose entre metodologías y conceptos diversos: eficacia simbólica (Lévi-Strauss 1968; Bourdieu 2009) ${ }^{3}$, drama social (Turner 1980) ${ }^{4}$, juego (Goffman 1961; Turner 1980) o performance (Schechner 2000; Goffman 2001; Turner 2002). Estas diferentes miradas implican que el ritual se replantee continuamente como objeto de debate, enriqueciéndose así las teorizaciones hechas hasta el momento. En este sentido, diversos autores han tratado el tema del ritual/drama/celebración en las sociedades contemporáneas, realizando, incluso, una revisión sobre estos conceptos y el estado de la cuestión (García García 1991; Cruces y Díaz de Rada 1995). En el caso de la antropología andaluza, este tema ha sido centro de atención de investigadores como Rodríguez Becerra (1985, 2006), Briones Gómez (1997) o Moreno Navarro (1999 [1974], 2006b [1982]), quienes han edificado distintos marcos teóricos y metodológicos que han tenido calado y continuidad en muchos de los que fueron sus discípulos. No es la pretensión de este trabajo realizar un recorrido exhaustivo por las fuentes teóricas que anteceden y empapan de sentido nuestra investigación, pero es preceptivo señalarlas para situar conceptualmente la temática a tratar.

2 Véase Box Varela (2008), Richards (2010), Hernández Burgos (2011: 263-319), Rina Simón (2015, 2016, 2017) o Mancha Castro (2017, 2018), entre otros.

3 Partiendo de los planteamientos apuntados por Mauss (1979: 45-154) en su «Esbozo de una teoría general de la magia».

4 En palabras de García García (1991: 13), «hay en Turner una doble o múltiple utilización del término "drama" completamente intencionada. Semejanzas percibidas entre el ritual (en sociedades no industriales) y el teatro (en sociedades complejas), tales como la existencia de acontecimientos y procesos liminales en ambos y, sobre todo, una común función de metacomentario social, le sugieren la consideración de los rituales como acciones dramáticas y la traslación y experimentación al teatro de cursos y recursos de acción percibidos en los rituales». 
Decía Moreno Navarro (2006b [1982]: 294-295) que la Semana Santa andaluza

posee una triple significación que corresponde a tres niveles distintos de profundidad del fenómeno. [...] Las tres significaciones, aunque situadas a niveles distintos de profundidad cultural, se interfieren e interfluyen, dando como resultado esa realidad compleja, caleidoscópica, e incluso turbadora, que es hoy.

Estos tres niveles de significación serían el religiosoespiritual, el étnico-identitario y el ecológico-sensorial. Posteriormente, ampliaría al menos dos niveles más de análisis: el de las significaciones de sexo-género y el de las significaciones rituales urbanas (Moreno Navarro y Agudo Torrico 2012: 182). Es en este último nivel de significación -muy ligado al étnicoidentitario- en el que pretendemos focalizar la atención de nuestro relato.

Partiendo de que son diversos los niveles de interpretación del fenómeno, y que estos responden a los elementos clave -mayoritariamente inconscientesque conforman su naturaleza simbólica, podemos señalar que la Semana Santa supone un ritual religioso festivo en el que se pone en juego la relación de las personas con la divinidad cristiana-católica a través de ritos y actos icónicos -rememorando la pasión y muerte de Jesús y los dolores de María-, siendo este su nivel de significación más explícito. Sin embargo, y a mayor profundidad, también es un ritual en el que se establecen relaciones simbólicas entre la comunidad, las redes de parentesco y de afinidad y de grupos sociales entre sí, siendo un poderoso elemento de identidad sociocultural. Asimismo, es un ritual ecológico que pone en relación al ser humano con la naturaleza y con su naturaleza, con la trascendencia vital y con las condiciones ambientales de su espacio geográfico. Pero, desde finales del siglo XIX y sobre todo en la actualidad, es una fiesta teatral urbana que ritualiza la relación de la comunidad con el espacio público habitado y con las instituciones de poder económico-político y religioso, y que refleja las alianzas y tensiones sociales que pudieran existir en el plano simbólico.

Por todo ello, Moreno Navarro y Agudo Torrico (2012) -siguiendo a Mauss (1979)- la definen como un hecho social total, un complejo fenómeno sociocultural que implica diversas dimensiones de la vida social y simbólica, que agrupa a diferentes sectores y grupos sociales y que, por ello, posee diversos modos de ser vivido, entendido, explicado e interpreta- do, es decir, diversas significaciones, y que no se puede reducir su explicación a ninguna de ellas, debiendo ser abordado desde una perspectiva holística.

El propósito de este artículo es aproximarnos a la Semana Santa de Huelva desde uno de sus significados más profundos, la perspectiva analítica de una fiesta dramática urbana, espacio socio-simbólico de exhibición y disputa en el que se ritualizan las relaciones y tensiones entre los diversos grupos sociales, el espacio habitado -la ciudad- y los poderes religiosos y políticos que pugnan por liderar su control ${ }^{5}$.

5 Se ha empleado la etnografía como metodología fundamental en esta investigación, junto con otras estrategias metodológicas y técnicas complementarias como la observación científica sistemática, las entrevistas en profundidad, las tertulias y conversaciones más informales, la ingente recopilación de noticias de prensa, de documentos bibliográficos, de archivo, literarios e informativos y de elementos etnográficos visuales y audiovisuales. Si nuestra unidad de análisis era el ceremonial público de la Semana Santa de Huelva, atendiendo a las funciones que en él se ponían en juego, así como a sus modos expresivos con sus significados rituales urbanos, nuestras unidades de observación se correspondían con el conjunto de hermandades existentes y su puesta en escena pública. En este sentido, la observación fue participante y no participante, según el caso. Las observaciones se realizaron en una multiplicidad de espacios sociales y ceremoniales, tales como las procesiones de la Semana Santa de 2015 -asistiendo parcialmente a varios días en los años 2016 y 2017-, un arquetipo de cultos internos en tres cofradías de tipología diversa y diversos actos culturales, preparativos y de convivencia. Se realizaron un total de dieciséis entrevistas a informantes clave, con guiones de entrevista estructurada y semi-estructurada. La muestra seleccionada se conformó en base a los siguientes criterios: sexo-género, tipo de vinculación con sus cofradías, rol en el cortejo procesional y rol directivo. Sin embargo, el número de discursos de los que nos servimos fue mucho más amplio si atendemos a las incontables conversaciones informales y tertulias -no solo presenciales sino también a través de grupos virtuales de cofrades en Facebook- que tuvieron lugar durante los tres años de trabajo de campo in situ, así como a los discursos emanados de las fuentes hemerográficas y de otras fuentes documentales y bibliográficas no producidas por el investigador. Los principales diarios locales de prensa analizados fueron el Odiel (1937-1984) y el Huelva Información (1985-2017), atendiendo a las páginas relativas a la cuaresma y la Semana Santa de ambos períodos. Por su parte, la bibliografía preexistente nos permitió acceder a investigaciones que, además de servir para ilustrar el estado de la cuestión, nos reportaron multitud de discursos y relatos muy relevantes para el objetivo de la investigación. Por último, los elementos visuales y audiovisuales etnográficos se basaron en los producidos por el propio investigador durante el trabajo de campo por medio de la cámara fotográfica digital y el teléfono móvil, así como 


\section{CONFORMACIÓN, ESTRUCTURA Y TEMPORALIDAD DEL DRAMA RITUAL URBANO}

Decía Hobsbawn (2002 [1983]: 7) que las «"tradiciones" que parecen o reclaman ser antiguas son a menudo bastante recientes en su origen, y a veces inventadas». Aunque la Semana Santa onubense supone una práctica religiosa y festiva que hinca sus raíces fundacionales en la Contrarreforma, lo cierto es que el gran ceremonial urbano que la constituye en nuestros días como modelo estético-expresivo y significativo es de origen decimonónico. La configuración de la misma como fiesta ritual y teatral de carácter urbano se fraguaría entre el último cuarto del siglo XIX y el primer tercio del XX, en el marco de los esfuerzos del nacionalcatolicismo durante la Primera Restauración para recuperar el terreno perdido ante la descristianización de las clases populares. Con anterioridad, las procesiones de Semana Santa consistían en ritos ceremoniales populares más parecidos a lo que en la actualidad es un acto de vía crucis. Las andas solían ser de reducido tamaño, la música procesional era inexistente y la estética de la celebración era muy diferente de la que conocemos y con la que se identifica en nuestros días la Semana Santa andaluza.

Poco sabemos acerca de las procesiones penitenciales onubenses con anterioridad al siglo XVIII con la excepción del ceremonial de la cofradía del Santo Entierro, en el que se hacían representar los poderes eclesiásticos y civiles de la villa. El historiador local Díaz Hierro señala que, con anterioridad al sínodo de 1604 , las cofradías hacían estación de penitencia a la ermita de la Santa Cruz y, tras este, la misma pasó a ser realizada en las iglesias de San Pedro y de la Concepción ${ }^{6}$. A finales del XVIII, la Virgen de los Dolores procesionaba hasta San Pedro desde el convento de la Merced en Domingo de Ramos. El Nazareno hacía lo propio con las imágenes de Jesús, San Juan y la Virgen, que iban en unas pequeñas andas hasta la plaza de San Pedro para realizar el ejercicio del Sermón del Paso y teatralizar el encuentro en la calle de la Amargura. A las puertas de la ermita de la Soledad,

otros procedentes de archivos públicos y privados, estos últimos puestos a nuestra disposición por diversos informantes.

6 Hipótesis formulada en el artículo «Historial de la estación de penitencia de las cofradías de Huelva», hallado en la carpeta 292 del Fondo Díaz Hierro del Archivo Municipal de Huelva. el Santo Entierro escenificaba el Descendimiento de Cristo y colocaba la imagen-cadáver en una pequeña urna en la que sería procesionado. Al regreso, la Virgen de la Soledad se recogía en la cercana iglesia de San Pedro para, el Domingo de Resurrección, volver en procesión gloriosa y triunfal hasta su ermita, inaugurando el tiempo pascual.

Entre las tres últimas décadas del siglo XIX y las tres primeras del XX, se conformaría la Semana Santa de Huelva como la fiesta sensorial total que es celebrada en un engalanado gran teatro urbano efimero. Este nuevo modelo estético-expresivo, festivo, burgués y romántico, tomó sus novedosas formas del paradigma cofradiero sevillano y estuvo altamente influenciado por el papel que jugó en la práctica totalidad de las cofradías onubenses el (re)inventor de esa estética: Juan Manuel Rodríguez Ojeda ${ }^{7}$. Los pequeños pasos de antaño se convirtieron en los de dimensiones actuales, la música procesional comenzó a inundar el ceremonial, se engalanaba la ciudad de una primaveral estética efímera y la popularidad de la fiesta se incrementó extremadamente, fundándose, reorganizándose y revitalizándose la práctica totalidad de las cofradías del momento. A la altura de los años treinta del siglo pasado, podíamos leer reflexiones como esta:

Como fiesta puede considerarse como la más popular, porque de ella disfruta tanto el creyente como el no creyente, hasta tal extremo que estas manifestaciones religiosas están más bien conceptuadas en todas partes más como del pueblo que de la Iglesia ${ }^{8}$.

La Semana Santa, tal y como la entendemos y conocemos en nuestros días, es una fiesta teatral

7 Durante las dos primeras décadas del siglo XX, Rodríguez Ojeda diseñó nuevos hábitos nazarenos para las cofradías de los Judíos y el Santo Entierro. En torno a 1908 o 1909, la Virgen del Mayor Dolor de San Francisco procesionó con el antiguo palio y manto de la Esperanza Macarena de Sevilla -hoy propiedad de la sevillana cofradía de la Estrella-, el cual fue cedido a la corporación por el propio Rodríguez Ojeda. Asimismo, diseñó y bordó cuatro de los cinco pasos de palio existentes en la Huelva del momento: Dolores de los Judíos, Amargura del Nazareno, Dolores de la Vera Cruz y Soledad del Santo Entierro. En palabras de Martínez Velasco (2013: 96), el lápiz de Rodríguez Ojeda «diseñó nada menos que la Semana Santa tal y como la vemos hoy".

8 Palabras de Francisco García Prieto, presidente de la Agrupación de Cofradías de Huelva en 1935, en una nota dirigida al Ayuntamiento de Huelva con fecha de 20 de febrero de 1935. Cita extraída de Sugrañes Gómez (1988: 12). 
urbana que responde al modelo estético-expresivo y a los significados instituidos entre finales deI XIX Y principios del XX. Cuando llega el Domingo de Ramos, el tiempo social cotidiano es detenido y el marco urbano es fuertemente transformado, emergiendo un tiempo sagrado y una estética ciudad efímera, imaginada y recreada, donde el orden público es alterado y algunas normativas legales son claramente transgredidas en una continua metamorfosis diaria ${ }^{9}$. En ese escenario sagrado y dinámico en el que se convierte la ciudad idealizada y evanescente, se da toda una suerte de transformaciones ligadas a la secuenciación estructural del ritual dramático que es celebrado: los espacios se engalanan mediante estrategias decorativas y constructivas efímeras para ser más útiles a la finalidad ritual y bellos para los agentes rituales ${ }^{10}$ [Figura 1]; el tráfico rodado es suspendido en el centro histórico y en parte de los barrios por los que procesionan las cofradías; el tránsito humano se incrementa y se dirige en función de los itinerarios de las procesiones; los sujetos participantes se acicalan en base a las normas internas que conforman el código de la fiesta y, puesto que muchos van tapados con antifaces en lugares públicos, se da una manifiesta transgresión del marco legal y normativo estructural. Esta continua metamorfosis urbana efímera, que se va (re)actualizando diariamente, está subordinada a la caducidad del tiempo sagrado de la fiesta.

9 Egizabal Suárez (2013: 128) sostiene que «el espacio es más que el soporte físico donde se lleva a cabo la acción ritual, pasa a formar una parte importante del mismo ritual llegando en ocasiones a ser el objeto de éste». Iborra Torregrosa (2013) ha abordado el tema de la conversión de los espacios urbanos en escenarios sagrados a propósito de la Semana Santa alicantina, entendiéndolos como marcos integradores para la expresión simbólica, espacios convertidos en auténticos lugares (Augé 2000), es decir, en espacios continentes de historia, identidad, significación y procesos de relación social y simbólica. En palabras suyas: "Las celebraciones transforman el espacio urbano en escenarios sagrados en donde, por medio de la eficacia simbólica, se subraya la acción socializadora y de representación de la communitas» (Iborra Torregrosa 2013: 170).

10 Por toda la ciudad se encuentran diseminados múltiples azulejos cerámicos permanentes que representan a las diferentes imágenes sagradas de la Semana Santa. Sin embargo, en los días previos a la fiesta, el centro histórico y los diferentes barrios populares de la ciudad por los que transitan las cofradías son hondamente transformados con reposteros, doseles, colgaduras, flores, iluminación y otros elementos efímeros que potencian la sacralidad del espacio-escenario de la dramatización ritual.

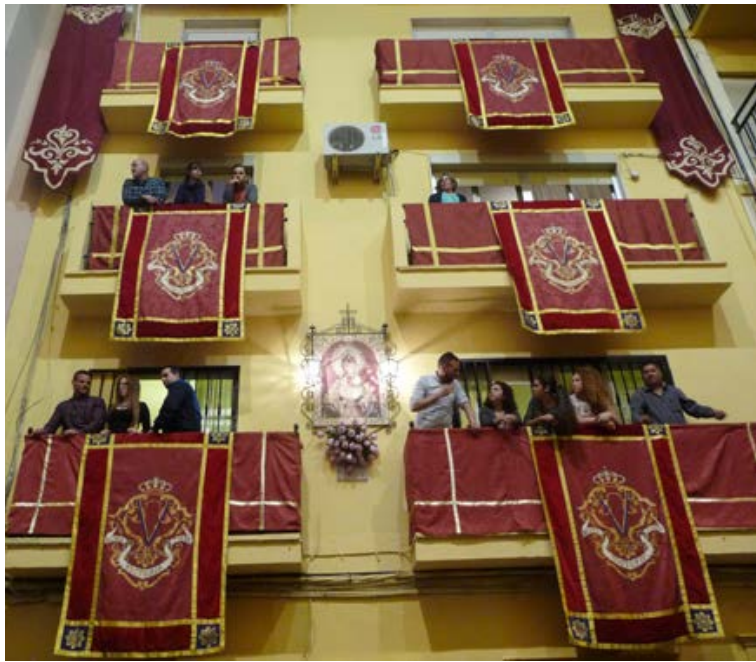

Figura 1.- Edificio engalanado con colgaduras y reposteros para los días de Semana Santa. Fotografía de José Carlos Mancha Castro.

La comunidad recreada a través de la acción ritual es un reflejo directo de la propia sociedad en la que la fiesta tiene lugar. El ritual, como proceso comunicativo y dramatúrgico revestido de simbolismo, supone una traducción de las distintas identidades presentes en el seno de esa sociedad. Para aproximarnos a esta idea, resulta de interés el concepto de drama ritual o drama social, derivado de los estudios de Turner $(1980,1988)$, que destacan «las sugestivas conexiones entre teatro y ritual» (García García 1991: 9). Aunque otros autores prefieren hablar de celebración (Cruces y Díaz de Rada 1995) o escenificación (Jiménez de Madariaga 2010), Gómez Lara y Jiménez Barrientos (1997: 151) denominan drama ritual urbano a un concepto «desarrollado a partir del estudio de los ciclos de obras medievales en las ciudades europeas, las fiestas nacionales modernas en Occidente, los periodos festivos del calendario judaico o árabe o las grandes fiestas urbanas del hinduismo", y que aplican al estudio de la Semana Santa de Sevilla, entendida no solo como rito litúrgico de la Iglesia católica sino también como fiesta popular que se desarrolla en el marco urbano. Algunas de las características del drama ritual urbano son:

1. No está compuesto de un discurso unívoco y unilateral, sino que este integra diversas narrativas y significados. Se da por la existencia de una narrativa oficial de la fiesta -la liturgia católica- que adquiere sentido y valor comunicativo en la calle. Las diferentes narrativas organizan el tiempo festivo y ofrecen múltiples formas 
de integración en las celebraciones, a la vez que permiten articular a los asistentes una historia imaginaria y simbólica del evento y del espacio donde se da.

2. Las características esenciales del drama ritual son la improvisación y la innovación -ya que se (re)actualiza de forma continua y permanente-, así como la imitación y el contagio mágico por contacto $^{11}$.

3. El vínculo que se establece entre la mayoría de los participantes y el núcleo organizativo responde al modelo de alianza social definido como débil ${ }^{12}$.

4. Los aspectos comerciales son inherentes debido al medio geográfico y social en el que tiene lugar el ritual: la ciudad. En este sentido, se considera que el gasto superfluo, la abundancia compartida, no es un elemento distorsionador, sino central y cohesionador.

Esta conceptualización de la ciudad recreada y (re) producida social y simbólicamente como escenario dinámico y dialéctico ha sido una constante en las fiestas y rituales públicos desarrollados a lo largo de la tradición cultural de los pueblos mediterráneos. En diversas culturas mediterráneas, siempre se han organizado desfiles rituales -dramatizaciones- que representaban a las fuerzas sociales dominantes, contando con ancestrales precedentes, como los casos de las procesiones de las ciudades griegas y romanas - las ejecuciones públicas medievales. Esta lógica se halla incardinada en toda una cultura de mostrar y representar, de utilización del marco urbano como

11 Jiménez de Madariaga (2008) señala que gran parte de la eficacia simbólica del ritual de la Semana Santa se basa en la misma lógica de lo que Frazer (1944) denominó magia homeopática o imitativa y magia contaminante. Atendiendo a la primera, imitando la pasión y muerte de Cristo, tanto en la iconografía de los pasos como en la escenificación de los cortejos, se pretende conseguir el mismo efecto: redimir los pecados. Con respecto a la lógica de la magia contaminante -dos cosas que estuvieron en contacto directo mantienen su influencia una vez separadas-, esta se encuentra en muchas prácticas como tocar a las imágenes o a sus pasos, coger una flor u otros elementos que han estado en contacto con los mismos, pasar un objeto por el ajuar de vírgenes o cristos, etc.

12 Este modelo de alianza social hace referencia a «un amplio conjunto de relaciones de apoyo social cuyos agentes no están involucrados en la red de relaciones vinculantes de familia y amigos [...] este modelo de relaciones sirve para minimizar la obligación del individuo y limitar la relación misma» (Adelman et al. 1993: 6, citada en Gómez Lara y Jiménez Barrientos 1997: 161). escaparate vivo, como espacio de exhibición, interacción o competición entre un conjunto de acciones simbólicas.

Desde esta perspectiva, Moreno Navarro y Agudo Torrico (2012: 182) han interpretado la Semana Santa andaluza como un ritual de reivindicación simbólica del derecho a la ciudad ${ }^{13}$. Sostienen que durante los días de Semana Santa se expresa la declaración simbólica de multitud de personas de su derecho a vivir y disfrutar la ciudad, es decir, a reafirmar su pertenencia a una determinada identidad grupal o comunitaria. Esto se demuestra con la ocupación de los centros histórico-simbólicos del núcleo urbano por gente de todas las edades, ideologías y condiciones sociales durante muchas horas del día y la noche. Muchas de estas personas proceden de barrios alejados del casco histórico o incluso viven forzosamente fuera de la ciudad y, bien para procesionar con sus cofradías o bien por querer disfrutar de las que procesionan cada día, vuelven a su ciudad de origen o recorren varios kilómetros hasta el casco histórico para reafirmar su pertenencia a la comunidad mediante la participación en sus prácticas festivas tradicionales, rechazando simbólicamente la subalternidad, la exclusión o la ausencia forzosa.

Martínez Kleiser (2003 [1924]: 11) describe la Semana Santa como el resultado de "la suma de varios esfuerzos aislados e independientes que se agrupan en un todo anárquico, incongruente, inconexo, laberíntico. Cada Cofradía es una entidad autónoma que acude, en santa rivalidad con sus hermanas, al festejo piadoso, como a justa vanagloria, ante el jurado popular». Esta perspectiva supone entender la fiesta como un concurso de teatralidad urbana; la Semana Santa como una escenografía romántica y barroca, de carácter dramático-vivencial-lúdico. Y coronando esa función de concurso teatral en el que la ciudad es embellecida y transformada en un escenario dinámico y dialéctico, se establece una via triumphalis ${ }^{14}$

13 Toman el concepto de derecho a la ciudad de Lefebvre (1978: 123), quien entiende que el ser humano tiene la necesidad de gastar y derrochar energías en el juego social, "la necesidad de actividad creadora, de obra (no solo de productos y bienes materiales consumibles), de necesidades de información, simbolismo, imaginación, actividades lúdicas».

14 Esta conceptualización fue acuñada por David Florido del Corral en "La Semana Santa Andaluza. Complejidad de significados y riqueza expresiva», ponencia no publicada, 2005. Utilizo esta anotación para agradecerle que me la 
denominada carrera oficial, esto es, un espacio público privatizado (Jiménez de Madariaga 2010) por el que discurren de manera obligada todas las cofradías ante una audiencia que paga un precio por una localidad [Figura 2] ${ }^{15}$. Este recorrido oficial es erigido en el centro histórico comercial, donde también se encuentran establecidas las sedes institucionales de los poderes políticos y eclesiásticos de la ciudad. A lo largo del trayecto por este recorrido, cada uno de los pasos de las diferentes cofradías es detenido frente a los palcos que ocupan los representantes de las tres instituciones que se reparten la organización y el control del ceremonial: el Consejo de Hermandades, la Iglesia católica diocesana y el Ayuntamiento.

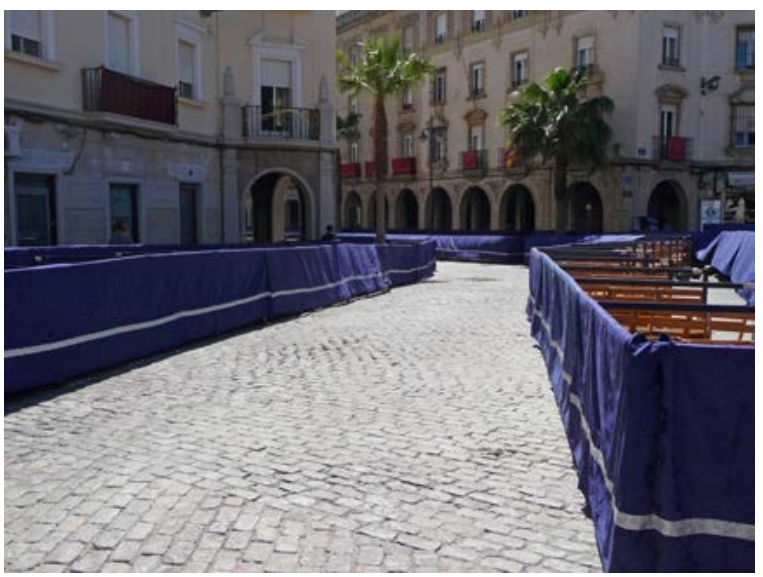

Figura 2.- Palcos de la carrera oficial de Huelva. Fotografía de José Carlos Mancha Castro.

En Huelva, el paso de las cofradías de Semana Santa por un recorrido oficial determinado ha ido trasladándose en función de los cambios de emplazamiento de los centros institucionales de los poderes económico-políticos y religiosos. Hasta mediados del siglo XIX, las cofradías se dirigían a la plaza de San Pedro, donde se ubicaban las casas del cabildo y la iglesia arciprestal. Con posterioridad, el lugar de paso obligado se estableció entre las calles Puerto, Botica y Concepción, enclave al que se trasladó el ayunta-

hiciera llegar bajo el propósito de que sirviera a los fines de esta investigación.

15 «Las calles y plazas de la Carrera Oficial dejan de tener su función habitual para convertirse en grandes escenarios donde sólo aquellos privilegiados que hayan pagado un asiento -la silla- podrán acceder. Los dirigentes municipales apoyan estos planteamientos de privatizar durante una semana espacios que en principio son públicos por la evidente rentabilidad económica y política que de ello se deriva» (Jiménez de Madariaga 2010: 10). miento y donde vivían los más importantes personajes industriales y financieros de la ciudad. Este hecho hizo que pasara a realizarse la estación penitencial en la otra iglesia principal de Huelva, la Concepción. Ya en el franquismo se institucionalizaría una nueva carrera oficial, pasando a ocupar un itinerario -con leves pero constantes modificaciones- entre la calle Concepción y la Gran Vía ${ }^{16}$. En esta última arteria se instituyeron y concentraron en los años cincuenta las nuevas sedes de los poderes económico-políticos municipales y provinciales (el consistorio, el gobierno civil, el Banco de España y la subdelegación de Hacienda), quedando la iglesia de la Concepción como centro religioso-católico donde realizar la estación penitencial.

Las preceptivas paradas de los pasos de las cofradías ante los palcos del Consejo de Hermandades, del Ayuntamiento y ante el templo representante de la Iglesia católica local, sancionan el reconocimiento de que esta trinidad institucional detenta la autoridad y ejerce el control sobre la organización de la Semana Santa. El primer palquillo ante el que se detienen y piden la venia para iniciar el recorrido oficial es el del Consejo de Cofradías, instalado al comienzo de la carrera. Posteriormente, paran los pasos y hacen la estación de penitencia en la iglesia de la Concepción, que representa la sede del poder eclesiástico ${ }^{17}$. Una vez consumado el rito religioso, las cofradías se dirigen por el resto del itinerario oficial, compuesto por la plaza y las calles más castizas de la ciudad, hasta llegar a la Gran Vía, donde detienen sus pasos ante el palco de autoridades civiles, colocado a las puertas del consistorio.

Como todo proceso ritual, la Semana Santa tiene una estructura y una dimensión temporal internas. La lógica estructural interna, esto es, la configuración del entramado ceremonial de la Semana Santa y la

16 Un recorrido por las carreras oficiales que han presidido la Semana Santa onubense en Sugrañes Gómez (1994).

17 Esta iglesia hace las funciones de sede del poder eclesiástico, lugar en el que las cofradías deben detenerse para realizar la estación de penitencia, acto religioso central de la procesión de cada una de las hermandades. Lo preceptivo sería que esas funciones religiosas se realizaran en la catedral, pero las particularidades del templo catedralicio de Huelva -de reducidas dimensiones y ubicado algo alejado del centro de la ciudad- hacen que no sea posible. La mejor ubicación geográfica de la Concepción, parroquia establecida en el corazón del casco histórico y más cercana las sedes del poder civil, resultó determinante para su elección como lugar donde realizar la estación. 
organización de las procesiones de las cofradías, no está ligada a una reproducción diacrónica de las escenificaciones de los momentos de la pasión y muerte de Jesucristo. El discurso diariamente consagrado en la calle, con esa anárquica representación de los pasajes del deicidio, salteados y desordenados, difiere del argumento secuencial de la narrativa evangélica. Es cierto que, a su paso por la carrera oficial, la narrativa de la fiesta empieza con la procesión de la Entrada Triunfal de Jesús en Jerusalén (la Borriquita) y acaba con la de la Virgen de la Soledad del Silencio, alfa y omega del ceremonial. Sin embargo, el resto de la representación dramática semanal se estructura en base a un orden particular que parece desordenado si solo se atiende al discurso bíblico. Esa anárquica estructura responde a factores históricos, sociológicos y simbólicos propios de cada cofradía.

Al igual que la asignación del día de salida de cada cofradía, el paso diario de las hermandades por el recorrido oficial tampoco guarda una lógica secuencial basada en la narrativa de los pasajes de la pasión y muerte de Jesús. La lógica estructural interna del ritual viene marcada más por la propia historia de la fiesta que por la historia conmemorada. En el caso del paso de las cofradías por la carrera oficial, la estructuración está basada, fundamentalmente, en el prestigio y la antigüedad de cada hermandad en el día de salida establecido. De esta manera, las hermandades fundadas más recientemente son las primeras que pasan por la carrera oficial, mientras que las más antiguas son las que la suelen cerrar ${ }^{18}$.

Previo a los días históricos de la Semana Santa Jueves y Viernes Santo-, se hallan las demás jornadas pasionistas, que vienen a coincidir con los días finales de la cuaresma. Estas jornadas, a excepción del Miércoles Santo, tienen una antigüedad no mayor de un siglo. Esta dilatación del tiempo festivo en la historia se ha dado, de forma secuencial, desde el Jueves Santo hacia atrás. A finales del XIX, la Semana Santa de Huelva se reducía a las procesiones del Jueves Santo, la Madrugada y la tarde del Viernes Santo. En 1894, comenzó la ampliación de los días procesionales con la incorporación de la cofradía de San Francisco a la jornada del Miércoles Santo. En 1918, se ampliaría al Martes Santo con la fundación de la hermandad de Pasión. En los años treinta se sacaron

18 Esta lógica, sin embargo, ha sufrido algunas pequeñas modificaciones debido a recientes acuerdos organizacionales entre el Consejo de Hermandades y varias cofradías. procesiones en el Lunes Santo, que se institucionalizaría como jornada cofradiera a partir de 1945. Por su parte, en 1943, el comienzo de la fiesta se concretó en el Domingo de Ramos y, apenas dos años después, la víspera se trasladó a la semana previa, con la celebración del pregón de la Semana Santa.

Esta secuenciación hacia atrás es ejemplo manifiesto de la deseada ampliación por los límites de la dimensión del tiempo de fiesta, que tiende a comenzar cuanto antes y que, en la actualidad, se alarga durante toda la cuaresma. Desde una mirada antropológica, la cuaresma no puede ser entendida en el sentido que le confiere la religión católica, como tiempo litúrgico de conversión, ayuno o reflexión para la penitencia. En el imaginario colectivo cofradiero, supone un tiempo festivo de vísperas y preparación ritual, lo que Van Gennep (2008 [1909]) y Turner (1988) denominaron fase de separación. A medida que «avanza la Cuaresma se produce un progresivo incremento de la tensión pre-ritual» (Rodríguez Mateos 1998: 256). Las diferentes actividades que en ella se suceden -cultos, vía crucis, besapiés y besamanos, conciertos, pregones, presentaciones de enseres de estreno, ensayos de costaleros, montajes, mudás o retranqueos de pasos ${ }^{19}$ - tienen como propósito preparar, anunciar y evidenciar el advenimiento del tiempo sagrado.

$\mathrm{Si}$, con anterioridad a los años ochenta, los actos inaugurales del tiempo festivo eran el pregón de la Semana Santa y el Vía Crucis oficial, que se situaban en días previos a la Semana Santa, en la actualidad ese tiempo de fiesta ha sido extraordinariamente alargado hasta el comienzo de la cuaresma. Ahora, el Vía Crucis oficial se celebra en las primeras semanas del tiempo cuaresmal y multitud de actos completan los menos de cuarenta días de preparación hasta alcanzar el inicio de la Semana Mayor. Este inicio se establece en la mañana del Domingo de Ramos, momento en el que los sujetos liminales concretan su

19 La mudá es el traslado de un paso desde el almacén en el que se encuentra todo el año hasta la iglesia, donde será arreglado para la salida procesional. Este traslado se realiza en fechas próximas a la Semana Santa, normalmente una o dos semanas antes. Por su parte, el retraqueo es el acto en el que se prueba, levanta y mueve con fuerza el paso, para comprobar que todo el aparato que se ha montado sobre el mismo está en perfecto estado y precisamente colocado. Tanto para la mudá como para el retranqueo es imprescindible la participación de la cuadrilla de costaleros. 
incorporación a lo que Turner (1988) denominó como período de margen. La cuaresma es la parte del tiempo festivo que actúa como preludio del tiempo sagrado, es decir, un período liminal que concentra los primeros efectos, sensaciones y emociones que van a inundar el tiempo sagrado ${ }^{20}$. Para el cofrade, la verdadera cuaresma religiosa, entendida como el tiempo de penitencia y abstinencia, es el resto del año, el tiempo social cotidiano, que es el tiempo de la espera, el que es descontado y calculado para la llegada de una nueva Semana Santa.

Con anterioridad a la Guerra Civil, el clímax de la celebración pasionista se hallaba en las jornadas finales, concretamente en la procesión del Nazareno al alborear de la Madrugada y en la tarde del Viernes Santo, con la solemne salida procesional del Santo Entierro y la icónica procesión del Silencio, antaño realizada por la hermandad de la Vera Cruz. Esto era debido a que la Virgen de la Soledad del Santo Entierro y el Nazareno representaban las dos devociones más arraigadas en el pueblo onubense. Acabada la guerra, esta lógica devocional y dramático-vivencial se transformó y surgieron nuevos iconos de identificación colectivos que irían dejando un notable poso con el paso de las décadas ${ }^{21}$. Esas flamantes devociones serían las de las nuevas vírgenes de la Victoria y la Esperanza y el Señor de Pasión, que en la posguerra tomarían un significativo auge devocional, manteniéndose como secular devoción popular la del Nazareno.

En la actualidad, el clímax de la fiesta se halla en los días intermedios y (pre)finales, coincidiendo estos con el Miércoles, el Jueves y el amanecer de la Madrugada del Viernes Santo, días grandes de la Semana Santa onubense. El primero es el día de la Esperanza y la Victoria, devociones marianas mayoritarias del siglo XX y XXI. Durante las procesiones de estas vírgenes, los asistentes les dedican constantes aplausos y gritos de «iViva!». Para Briones Gómez (1997: 210), esos «vivas» dan «el contrapeso de alegría, vida y triunfo a todos los signos de tristeza y de muerte»

20 Entendemos el tiempo sagrado como la fase final y de mayor intensidad del tiempo festivo, la que concentra la salida de las procesiones desde el Domingo de Ramos hasta el Viernes Santo. Es al comienzo del tiempo sagrado cuando se produce la inmersión total y definitiva del sujeto ritual en el período de margen.

21 Para un análisis de las transformaciones de la Semana Santa de Huelva tras la Guerra Civil, véase Fernández Jurado (1997), Moreno Navarro (2006a: 268-280) y Mancha Castro (2017, 2018). que inundan el complejo ceremonial de la Semana Mayor. El Jueves Santo y la Madrugada suponen las jornadas clásicas de la Semana Santa castiza, donde cuatro de las cinco cofradías que desfilan son anteriores al conflicto guerracivilístico y poseen un innegable prestigio y status cofradiero. Son dos jornadas que concentran un destacado patrimonio históricoartístico y etnológico, así como momentos rituales de marcada tradición en la memoria colectiva local. En la Madrugada onubense solo procesiona la cofradía del Nazareno, el Padre Jesús de la localidad. Es la devoción cristífera por antonomasia de los onubenses que, al amanecer del Viernes Santo, abarrotan la zona de la antigua pescadería y lo acompañan hasta su recogida en la parroquia de la Concepción ${ }^{22}$.

En la tarde del Viernes Santo, última jornada de cofradías en la calle, se ritualiza una luctuosa doble significación en torno a las dos Soledades que procesionan. El solemne y oficialista desfile procesional del Santo Entierro simboliza el luto popular e institucional por la muerte de Jesús. A la Virgen de la Soledad de esa cofradía la acompañan multitud de autoridades civiles y militares y una representación de la jerarquía eclesiástica, con el obispo diocesano a la cabeza [Figuras 3 y 4$]^{23}$. Por su parte, la procesión de la Virgen de la Soledad de la hermandad del Silencio es la secuencia ritual que simboliza la conmiseración de la Mater dolorosa, icono femenino-materno que anuncia la venida de la tristeza por la fiesta que acaba y que -paradójicamente- acompaña a sus hijos-cofrades en el duelo del tránsito final por el tiempo sagrado de la fiesta, llorándose la defunción de la Semana Santa.

22 Tanto Briones Gómez (1997) como Moreno Navarro (2006b) han interpretado la significación del icono del Padre Jesús Nazareno como la imagen-símbolo que refleja la memoria colectiva de opresión del pueblo. Con esa imagen simbólico-identitaria que refleja al hombre justo que carga injustamente con la cruz, ese pueblo simboliza su propia experiencia de opresión colectiva, recreando la tragedia de Jesús.

23 Las tres autoridades representantes de los tres poderes que controlan y organizan el ritual -el alcalde (autoridad civil), el obispo (autoridad religiosa) y el presidente del Consejo de Hermandades (autoridad cofradiera)-, se hacen representar en diferentes presidencias en esta cofradía del Santo Entierro. El alcalde y el presidente del Consejo, con su séquito de concejales del ayuntamiento (a excepción de los ediles de partidos laicistas) y los directivos del Consejo de Hermandades, van en sus respectivas presidencias en los cortejos de la urna y del paso de virgen, mientras que el obispo va situado como preste, cerrando el cortejo tras el palio de la Virgen de la Soledad. 


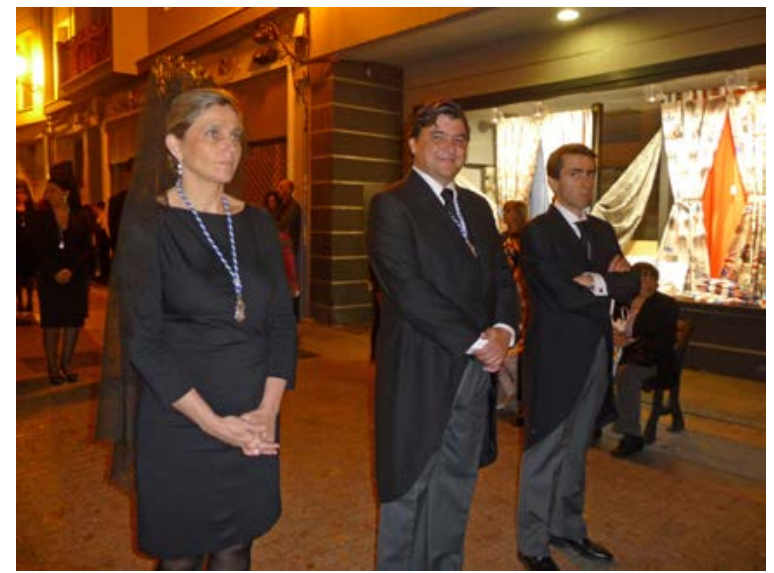

Figura 3.- Representantes del PSOE de la corporación municipal en el cortejo del Santo Entierro. Las mujeres participan ataviadas con mantilla negra, mientras que los hombres visten chaqué. Fotografía de José Carlos Mancha Castro.

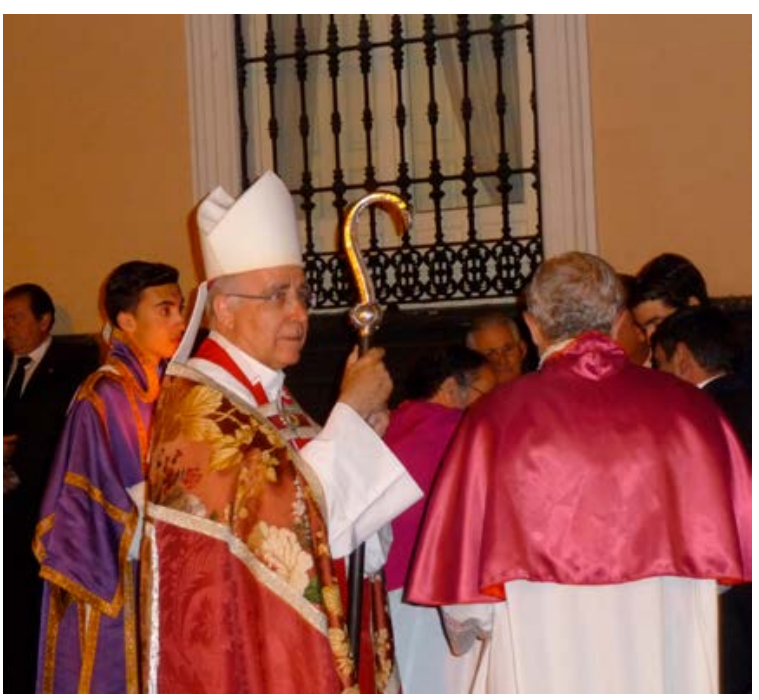

FIgURA 4.- Obispo de Huelva participando como preste tras el paso de palio de la Virgen de la Soledad de la cofradía del Santo Entierro. Fotografía de José Carlos Mancha Castro.

En base a esta dual representación icónica de la Soledad de la Virgen, se articulan dos maneras de llorar la conclusión de las narrativas que cubren de sentido el drama ritual. La Soledad del Santo Entierro simboliza y acapara el acompañamiento y consuelo que se le ofrece a la Madre de la Iglesia católica, el rito de pésame oficial anual por la muerte del Señor, su Hijo. Esta narrativa articula el mensaje religioso de la Iglesia institucional, al que se suman los poderes cívico-militares locales y provinciales. Por otro lado, la Soledad del Silencio es el icono que sentencia que todo se ha consumado, que anuncia la tristeza por el fin del tiempo sagrado de la fiesta, de la liminaridad y la communitas, y que simboliza el tránsito hacia el final del es- tado de fiesta ${ }^{24}$. Esa tristeza generalizada en torno a la imagen-símbolo de la última Soledad se debe no a la pérdida simbólica de Jesús sino de la Semana Santa, convirtiéndose esa procesión en todo un rito de paso, en la conmoción que inicia la fase de reagregación de los sujetos liminales que han participado en el ritual, que de nuevo se incorporan al tiempo social cotidiano. Utilizando las palabras de Machuca (2013: 125), esa Virgen de la Soledad «es el dolor en el costado de una ciudad que pierde lo que ama».

\section{ESTRUCTURA, SIGNIFICACIONES Y SIMBOLISMO DE LOS CORTEJOS CEREMONIALES}

La calle es el escenario dinámico y dialéctico en el que tiene lugar la dramatización ritual de la Semana Santa, y es en la calle donde toma sentido y significado el ceremonial que pone en juego cada cofradía a través de su procesión. Las procesiones de Semana Santa están constituidas por una amalgama de símbolos de naturaleza diversa que, en conjunto, forman una estructura ritual sincrética, extremadamente rica y compleja. Se organizan al modo de una comitiva fúnebre de enterramiento que fusiona elementos y significados católicos con otros de tipo festivo-popular, cofradieros, militares, cívico-institucionales, etc. Los cortejos cuentan -en su mayoría- con dos pasos, y son abiertos por una cruz que es seguida por un conjunto de individuos, llamados nazarenos o penitentes. Tras ellos, va el féretro -representado por el paso de cristo-, al que también siguen penitentes $y$ nazarenos. Cierra el cortejo la virgen-madre del difunto a la que acompañan el cura y el pueblo, situados tras su paso (González Isidoro 2004: 41) ${ }^{25}$. En

24 Los cofrades que experimentaron la liminaridad y que conformaron la communitas se convierten en seres de tránsito, en trance, transeúntes de una modalidad de relación social a otra. "No es casual que, en algunos idiomas como el catalán, trance -como "éxtasis"- y tránsito -en el sentido de "tráfico" o "movimiento"- requieran un mismo término: trànsit. [...] transeúnte, es decir persona que está en tránsito, en passage. Tránsito, transeúnte, del latín transeo-pasar, ir de un sitio a otro, transformarse, ir más allá de, transcurrir, recorrer rápidamente...-, cuyo participio es transitus: acción de pasar, de cambiar de condición» (Delgado Ruiz 1999: 119-120). En este día que clausura la Semana Santa, el cofrade es un ser liminal, en trance, que transita de una fase liminal a otra que le devuelve al tiempo social donde la fiesta se ha desvanecido.

25 En el caso del cortejo del paso de cristo o de misterio se puede interpretar una segunda significación. En el Antiguo 
base a esta estructura, cada cofradía «articula un complejo simbólico de jerarquía y status que se expresará a través de la posición ritual» de los participantes (Rodríguez Mateos 1998: 259) ${ }^{26}$.

Los cortejos procesionales se encuentran conformados por tramos de nazarenos que van colocados por parejas y portando cirios. Los nazarenos de las cofradías que visten hábitos con capa portan la cera suspendida o a modo de cetro. Los que visten hábitos de cola o de sotana la portan al cuadril, es decir, adosando el cirio a la cintura y apuntando hacia arriba [Figuras 5 y 6]. Cada tramo va separado por las insignias de la cofradía, que son escoltadas - unas- con varas y otras- con faroles, a excepción de la cruz parroquial que va flanqueada por dos ciriales. Las insignias pueden ser de diferente naturaleza: religiosas, cívico-militares, locales, conmemorativas e institucionales ${ }^{27}$.

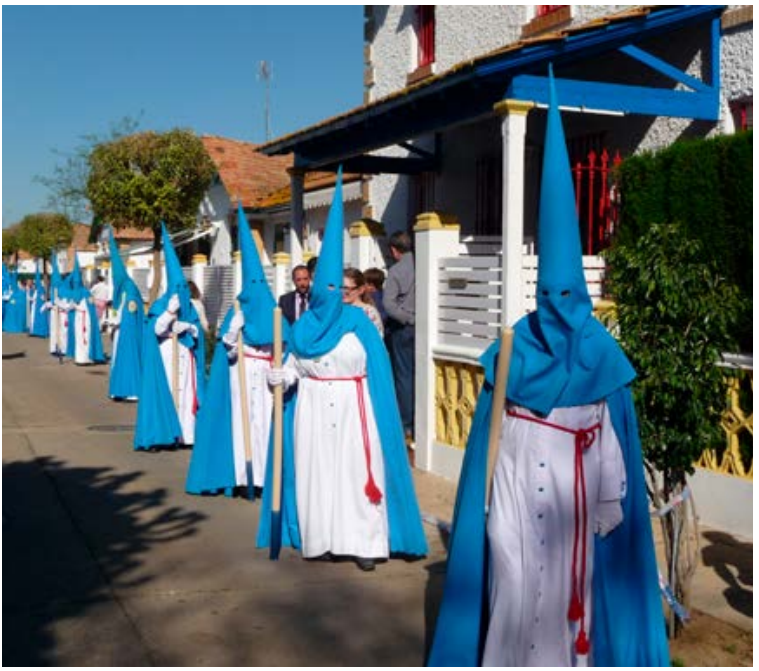

Figura 5.- Nazarenos de la cofradía de la Victoria portando el cirio suspendido al ser una cofradía de capa. Fotografía de José Carlos Mancha Castro.

Régimen se dramatizaban las ejecuciones, así como el tránsito hacia el cadalso del sujeto que iba a ser ejecutado, dramatizaciones que eran de carácter público. El cortejo del paso de cristo, con su estilo marcial, con sus redobles de tambores y sus sones de cornetas, representa y simboliza también la procesión del reo que es conducido al patíbulo.

26 «La antigüedad y, sobre todo, el status serán los criterios usados y aceptados por el común de los cofrades para el ascenso dentro de esta jerarquización ritual: [...] la cercanía con respecto a la imagen-símbolo en la posición ritual denota status, prestigio y una sensación de participación mística» (Rodríguez Mateos 1998: 273).

27 Un análisis de las insignias en De la Campa Carmona (2004).

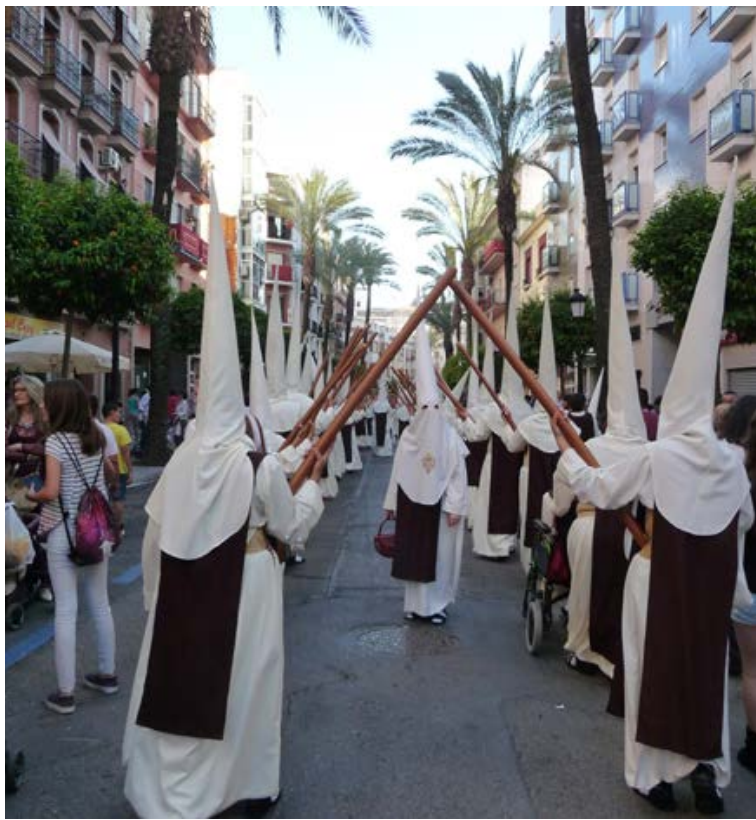

Figura 6.- Nazarenos de la cofradía del Prendimiento portando el cirio al cuadril al ser una cofradía de cola. Fotografía de José Carlos Mancha Castro.

En los cortejos procesionales, el control y la autoridad son detentados por el diputado mayor de gobierno. Este se sirve de un grupo de fiscales, que controlan los tiempos de paso, y de diversos diputados de orden, que organizan los tramos y velan por el correcto cumplimiento de las normas penitenciales establecidas por cada hermandad. En cada cortejo hay un fiscal en la cruz de guía [Figura 7], otro en el paso de cristo y otro en el paso de palio. El diputado mayor de gobierno, a través del fiscal de la cruz de guía, hace cumplir el horario e itinerario de la procesión y solicita la venia de entrada a la carrera oficial. Asimismo, por medio de los fiscales de paso, da la orden para que las andas procesionales avancen o se detengan. Tanto los nazarenos que escoltan cada insignia con varas, como el diputado mayor de gobierno y los fiscales, que portan los llamados palermos ${ }^{28}$, son individuos anónimos que detentan -unos- el prestigio y -otros- la autoridad ritual en la organización y el desarrollo de la procesión, que queda simbolizada con el elemento que portan. Las varas, las pértigas y los palermos son símbolos de dignidad y poder ritual, y son portados al modo de cetros [Figuras 8 y 9$]$.

28 Bastón de madera con contera metálica, que suele estar rematado por un pabilo o cordón. 


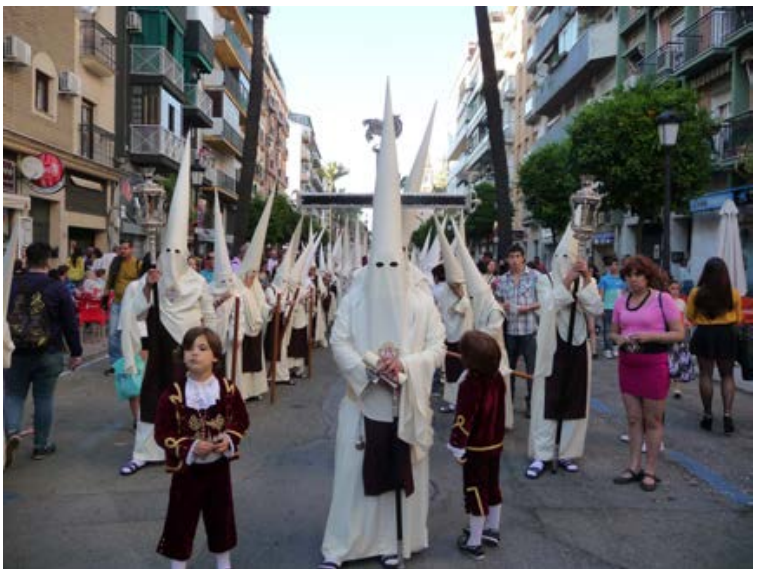

Figura 7.- Fiscal de la cruz de guía de la cofradía del Prendimiento. Fotografía de José Carlos Mancha Castro.

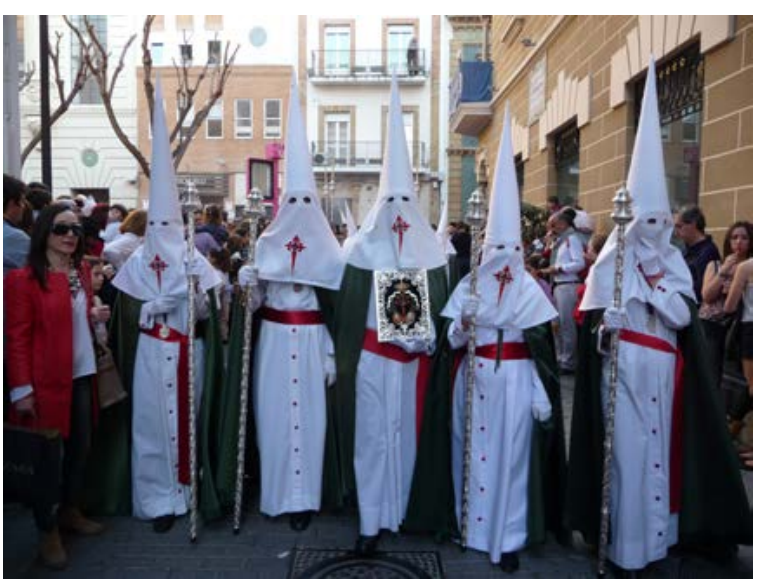

Figura 8.- Nazarenos con varas y libro de reglas de la cofradía de las Tres Caídas. Fotografía de José Carlos Mancha Castro.

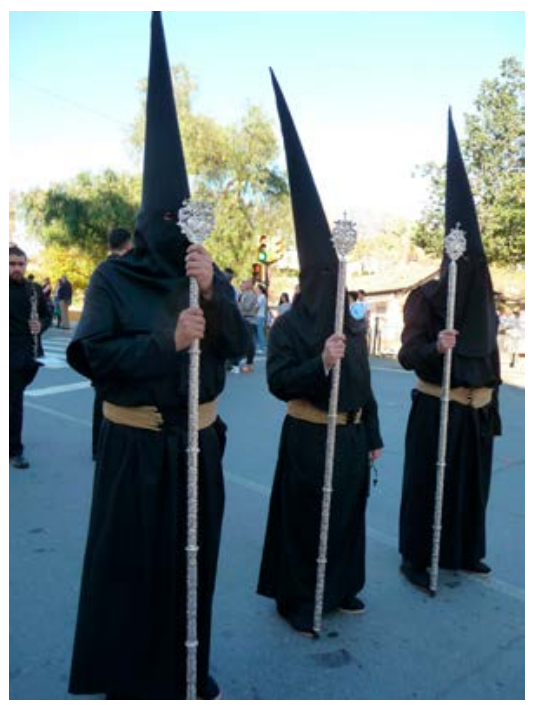

Figura 9.- Nazarenos con varas de presidencia de la cofradía de los Estudiantes. Fotografía de José Carlos Mancha Castro.
La figura del nazareno representa el icono del sujeto ritual prototípico de la celebración pasionista. En la actualidad, son diversas las significaciones que se derivan de la práctica de ataviarse como nazareno, y estas proceden de una dual interpretación del acto ritual. La acción de participar como nazareno puede partir de una perspectiva penitencial o de una perspectiva festivo-comunicacional que, además, pueden complementarse.

Partiendo de estas dos visiones, para unos, ataviarse con el hábito penitente, sería la acción de quien «busca el perdón a través de un gesto de pública humillación [...], cubriendo su cuerpo por la humildad de la túnica y buscando el encuentro interior del arrepentimiento» (Sugrañes Gómez y Gil-Mazo 1991: 4) ${ }^{29}$. En este sentido, el nazareno-penitente sería la personificación de un exvoto, una compensación simbólica dirigida a la divinidad con la ofrenda de una penitencia física y estética ${ }^{30}$ a cambio de un favor demandado o recibido. Sería la plasmación del pago establecido en una diádica relación contractual entre fuerzas asimétricas, entre una divinidad-patrona concedente y un devoto-cliente beneficiario, expresada a través de promesas o exvotos en un contexto inconmensurablemente simbólico ${ }^{31}$. En definitiva, una particular correlación religiosa basada en los principios de los sistemas de deuda que están en el origen de las relaciones entre los hombres y los dioses (Graeber 2014) ${ }^{32}$, expresados al modo de la cultura vernácula.

29 A lo largo de los siglos de historia de las cofradías penitenciales, muchos sujetos se han impuesto vestir una túnica de nazareno como acto de desagravio, como una pena simbólica por haber obrado mal en algún momento de sus vidas. En el franquismo, la hermandad de las Tres Caídas llegaba hasta la prisión provincial y, allí, liberaba a un preso, que acompañaba en penitencia a la cofradía por las calles. Hechos simbólicos como este aún siguen realizándose en nuestros días. La cofradía del Calvario suele introducir en su cortejo a internos de la cárcel de Huelva, vistiendo el hábito nazareno corporativo. Así lo especifica, por ejemplo, la crónica del diario Huelva Información de 23 de marzo de 2008, p. 20.

30 Rememorando la estética de un reo de la Inquisición y portando un sambenito (el capirote).

31 Rodríguez Becerra (2006) ha profundizado en la concepción religiosa de los andaluces como relación (simbólica y trascendente) de intercambio de contraprestaciones entre fuerzas actuantes en posiciones dispares: entre (devotos) sujetos demandantes y deudores y seres sobrenaturales dispensadores (imágenes sagradas).

32 La deuda primordial, la de la vida, a partir de la cual se instituye una relación divinidad-fieles en la que los sacri- 
Para otros sujetos, salir de nazareno puede ser una acción festiva, lúdica, sentimental e incluso considerada tradicional y popular, como demuestran las intenciones familiares de vestir a los niños y adolescentes de nazarenos en la procesión de la cofradía a la que pertenece la familia. El hábito nazareno es aquí un traje emotivo y de gala, que se porta de manera triunfal y que ofrece una imagen de orgullo personal e identitario ${ }^{33}$. En este sentido, muchos de los participantes también visten sus túnicas $u$ otros objetos rituales en recuerdo de sus parientes fallecidos, como rito conmemorativo, acto de inmersión en la memoria íntima y en los recuerdos personales y de las redes de parentesco, que contienen cargas de fuerte emotividad $^{34}$.

Asimismo, para otros cofrades, el hecho de vestirse de nazareno puede contener todos estos significados

ficios y las ofrendas, en sus distintas formas, vienen a recordar y aplazar (nunca a condonar definitivamente) el pago de esa deuda primigenia, que será satisfecho algún día con la muerte. No en vano - dice Graeber (2014: 102), la palabra alemana schuld significa "deuda» y "culpa» al mismo tiempo. Antiguamente, estar en deuda era ser culpable, y los acreedores disfrutaban castigando a los deudores incapaces de pagar (pecadores). Precisamente, una de las lecturas simbólicas de la figura de Cristo en la historia económica planteada por el antropólogo estadounidense, es que con el sacrificio perpetrado por el mismo Dios a través de su Hijo se produce una redención (que aspira a ser definitiva) de la Humanidad: "El significado original de "redimir" es recomprar algo, o recuperar algo que se había dado como aval en un préstamo; adquirir algo mediante el pago de una deuda. Es chocante pensar que el núcleo más íntimo del mensaje cristiano, la propia Salvación, el sacrificio del propio hijo de Dios para rescatar a la humanidad de la condenación eterna, se tenga que enmarcar en términos de una transacción comercial» (Graeber 2014: 106).

33 "Los incentivos de vestirse de nazareno desde pequeño, "siguiendo la tradición", suelen motivar suficientemente la adscripción infantil, y no es tanto la hermandad elegida como propiamente el hacerlo, pues vestirse de nazareno es también, y básicamente, un símbolo de identidad cultural» (Rodríguez Mateos 1998: 161). «hay muchos jóvenes que salen de nazareno porque les gusta, sin embargo, poco a poco irán tomando conciencia del significado de participar en una hermandad" (Palabras del presidente de la Unión de Cofradías, Juan José Redondo. Publicadas en el periódico Huelva Información de 27 de marzo de 1991, p. $6)$.

34 "Yo es que todavía salgo con la medalla vieja de mi abuelo, es ligazón de generaciones, es como un cordón umbilical que une a lo mejor a tres generaciones, y es simplemente un cordón viejo, ya despeluchado de una medalla» informante 1 de José Luis De Vicente Carmona (2010: 557-558). a la vez: ser algo festivo y emotivo, pero también un ejercicio espiritualmente profundo, de fuerte carga religiosa y/o penitencial, que une, sin la mediación de otros seres humanos, a la propia persona con la divinidad; así como también puede significar una práctica piadosa para prometer acciones, pedir o demandar favores terrenales a la deidad ${ }^{35}$. Pero en definitiva, desde todas estas perspectivas, lo que se viste es la prenda sagrada del ceremonial, por lo que no es extraño que la figura del nazareno sea la más representativa de cuantas componen el frondoso bosque de símbolos que conforma la Semana Santa ${ }^{36}$.

Una gran parte de los tramos de nazarenos de la mayoría de los cortejos procesionales onubenses se componen de niños. Muchos también suelen participar ataviados como monaguillos precediendo a uno de los pasos. Es común ver a los niños que visten de nazareno dar gotas de cera con su cirio a otros que ven la cofradía desde fuera y que portan multicolores bolas de cera, así como también es común ver a los monaguillos repartiendo estampitas de las imágenes de la cofradía y/o caramelos [Figuras 10 y 11] ${ }^{37}$.

35 Para algunos, vestir de nazareno significa portar un atuendo prestigioso, reservado para la comunicación directa con los seres trascendentes, con un capirote que simboliza un elemento de conexión fiel-divinidad, «una especie de antena del poder, un artilugio que comunica a su portador con la divinidad» (Rufino y Grosso 2014: 26), al modo de la mitra de los papas y obispos católicos, el mitznefet hebreo, los gorros cónicos de asirios e hititas, la tiara persa, la corona egipcia, el camelaucum bizantino o el gorro frigio. Estos elementos son símbolos de poder y, en el caso del antifaz y capirote de nazareno, de poder ritual y festivo, elemento reservado a los actores que protagonizan el rito procesional.

36 Para Moreno Navarro (2006b: 129), el encanto más profundo de vestirse de nazareno es "salirse de la cotidianidad; saberse y sentirse objeto de las miradas -y hasta de la envidia, si se es niño, de los otros niños que no se visten-, y a la vez conocer sin ser conocidos; saludar queda y misteriosamente a compañeros o amigos mientras éstos presencian la cofradía [...]. Protagonizar la Semana Santa, en definitiva».

37 En las únicas cofradías que no se observan niños vestidos de nazareno ni la acción de dar cera son aquellas que hacen gala de un riguroso silencio y un estricto sentido penitencial en su cortejo. En ellas, el espacio reservado para la participación de los niños es el cuerpo de monaguillos, al cual deben pertenecer hasta cumplir los catorce años. Son las cofradías más serias y ortodoxas de la Semana Santa y cumplen la función simbólica de la contraposición y del complemento dialéctico a los signos y símbolos de alegría y festividad. Un ejemplo de estas ascéticas hermandades son el Calvario, la Misericordia o la Santa Cruz. 


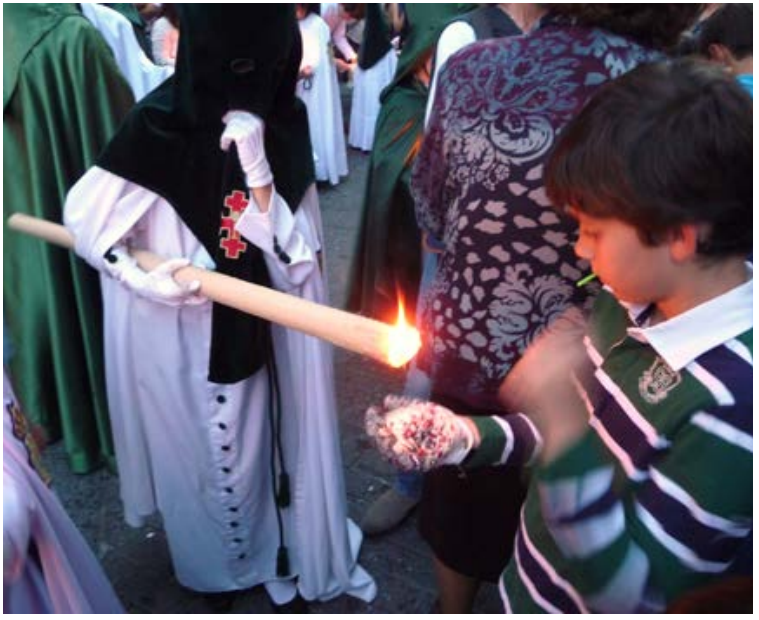

Figura 10.- Nazareno de la cofradía de San Francisco dando cera. Fotografía de José Carlos Mancha Castro.

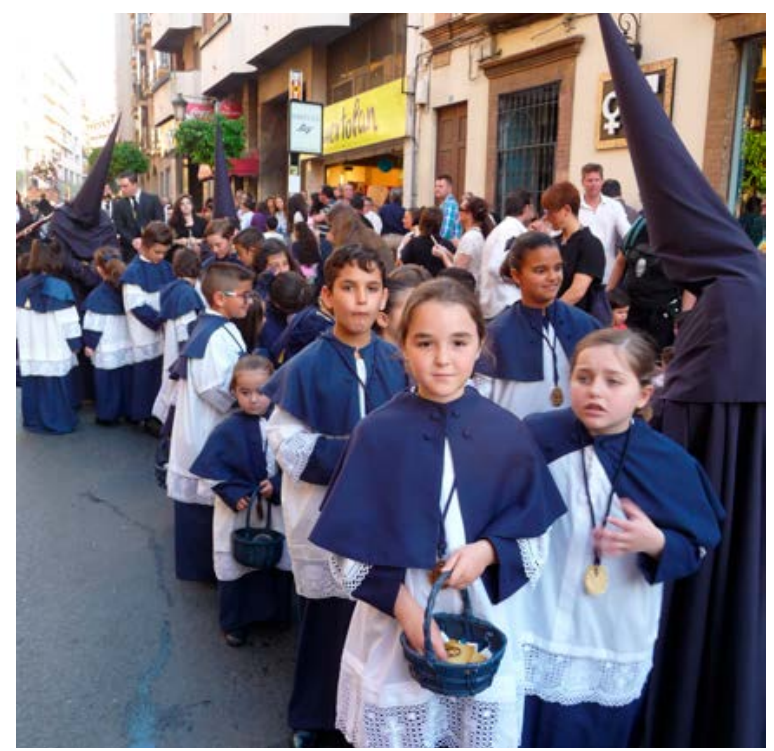

Figura 11.- Cuerpo de monaguillos de la cofradía de la Santa Cruz, portando cestitas con caramelos y estampitas. Fotografía de José Carlos Mancha Castro.

Esta acción de dar y pedir cera, caramelos y/o estampitas, como costumbre que se inculca a los niños que salen de nazarenos, de monaguillos o simplemente a ver las procesiones, es una manera de socializarlos en el ritual mediante el juego, como acto de diversión e interacción, en el sentido de Goffman (1961, 2016). Un juego que, a su vez, es todo un complejo simbólico de distribución, de derroche festivo, una forma de solidaridad interpersonal expresada de manera simbólica, vinculada a la acción del don (Mauss 1979), del presente y del obsequio, que traspasa y niega simbólicamente la socialización cotidiana en los valores utilitaristas y de acumulación de la lógica de mercado que inunda la concepción ideológica hegemónica de las sociedades capitalistas contemporáneas ${ }^{38}$. Todo este complejo simbólico del juego de pedir-dar cera, caramelos y estampitas es un excepcional sistema colectivo de reciprocidad, enmarcado y vinculado exclusivamente a la celebración ritual de la Semana Santa, es decir, con un sentido y una lógica radicados en el tiempo de fiesta, en la liminaridad y en la conformación de la communitas [Figura 12]. Obsequios y donaciones de características morales, rituales e identitarias, cuyo significado depende de y solo se entiende en la fiesta ${ }^{39}$.

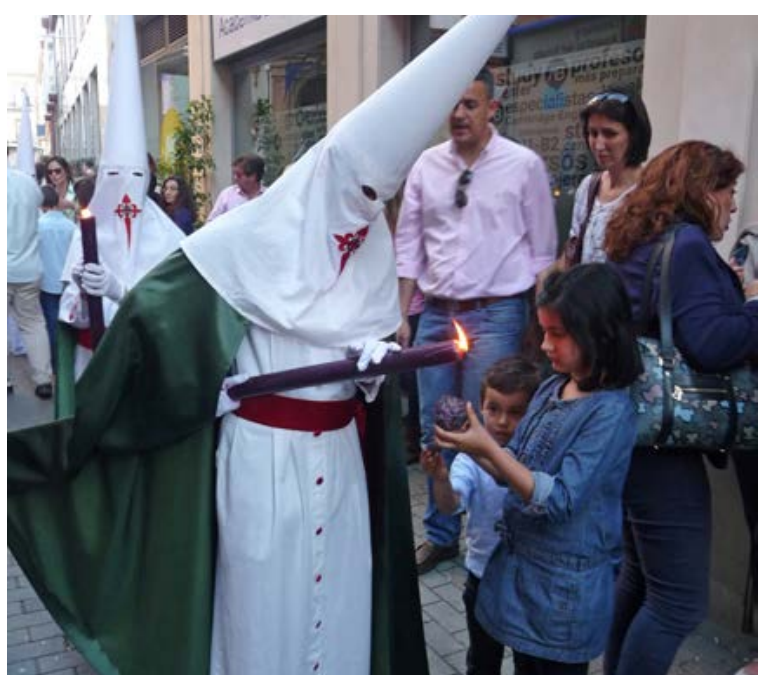

Figura 12.- Nazareno de la cofradía de las Tres Caídas dando cera. Fotografía de José Carlos Mancha Castro.

La cofradía genera una conciencia de nosotros simbólico, un sentimiento de pertenencia e identificación. Estas asociaciones, formalmente religioso-cristianas, funcionan como grupos sociales y rituales proveedores de identidad colectiva, como mecanismos de integración y pertenencia a un contexto festivo local, y ritualizan la reafirmación de ser parte de esa comunidad recreada, imaginada, igualitaria, ideal

38 «Los rituales tienen la doble dimensión de juego (play) y juego (game), de lo lúdico como tal y del juego de reglas. [...] Su eficacia reside en hacer tradición jugando con los cambios periódica e indefinidamente. En parte dramas y en parte juegos, dan a grupos e individuos el doble relieve procesual de la cultura» (García García 1991: 14).

39 «La entrega, el don [...] supone un reconocimiento, "tú eres parte de la fiesta", de carácter igualitario porque no es derroche que expresa el disfrute y la opulencia de una clase social acomodada que exhibe su poder o se jacta de acciones solidarias y dispendios con los más pobres o desfavorecidos. Es derroche festivo" (Guerrero Muñoz 2012: 623-624). 
y deseada. En la calle, escenario dinámico y dialéctico del drama ritual, la cofradía se revela como una efímera communitas que fagocita las diferencias sociales existentes entre los miembros ${ }^{40}$. En el acto ritual no existe distinción de orden social alguna porque todos (los hermanos participantes) son uno (la cofradía ${ }^{41}$ ), una unidad indisoluble y totalizante. Esto se observa muy claramente tanto en los cortejos de nazarenos como en ese ejemplo de trabajo religioso ${ }^{42}$ que es cargar un paso por parte de una cuadrilla de $\operatorname{costaleros}^{43}$. La diversidad estructural -social, ideológica, económica o de otro tipo- es subsumida por una communitas espontánea en la que han desaparecido las diferencias sociales y que es productora de un profundo igualitarismo en el que todos son uno en la religiosa tarea de hacer realidad, cada primavera, a golpe de llamador y tôh por iguâh ${ }^{44}$, la ópera socio-simbólica total de la Semana Santa.

Con la única división de la altura en la cuadrilla y de la antigüedad en el cortejo penitencial, el nosotros simbólico que es recreado durante unas horas consigue reproducirse en el ritual negando efímeramente las diferencias estructurales de orden social existentes entre los miembros. El único status que existe durante la dramatización es el de la cofradía como bloque, como grupo ritual que, en la turba de las

40 «La Semana Santa, por definición, es una práctica colectiva. [...] No existen individuos, solo el genérico sustantivo de lo que son o de lo que hacen: nazarenos, costaleros, penitentes, músicos, capataces, público...» (Rodríguez Mateos 1998: 258).

41 El término cofradía deriva etimológicamente del latín «cum frate (con el hermano)» (Sánchez Herrero 2003: 19).

42 Que religa, del latín religare: religar, atar fuertemente, volver a unir.

43 La función simbólico-ritual de los costaleros se identifica con la carga y los sufrimientos de Jesús, pero en lugar de cargar la cruz -como hacen simbólicamente los penitentes-, cargan -literalmente- con el peso de la pasión de Cristo o de los dolores de su Madre, estableciendo un extraordinario paralelismo simbólico entre la cuadrilla y el icono exaltado que les ha valido la denominación de «disciplinantes de la Modernidad» (Rodríguez Mateos 1998: 173).

44 La expresión "tôh por iguâh» (todos por igual) es utilizada por los capataces de los pasos a la hora de llamar a los costaleros justo antes del último toque del llamador, tras el cual alzan el paso. La transcripción ortográfica de la citada expresión la hemos tomado utilizando la herramienta «Trâccrîttôh Câtteyano-Andalûh (Transcriptor CastellanoAndaluz)", creada por el colectivo EPA (Er Prinçipito Andalûh). Para ahondar en el proyecto y la propuesta ortográfica de este colectivo de lingüistas andaluces, véase: https://andaluh.es/. calles, debe enfrentarse a sus otras cofradías-hermanas en sagrada rivalidad espiritual, estética y sensorial.

\section{CONCLUSIONES}

La Semana Santa está conformada por una lógica interna compleja, pluridimensional y multisignificativa. Esto quiere decir que puede ser experienciada, entendida y abordada desde una pluralidad de perspectivas que ofrecen una multiplicidad de significados, que son diversos, complementarios u opuestos, pero todos válidos para vivir, interpretar y explicar el fenómeno. Y esto es así porque en la Semana Santa se ponen en juego múltiples símbolos -que son polisémicos-, iconos, espacios temporales y urbanos, modos de comportamiento, maneras de desfilar y de ataviarse; se articulan diferentes narrativas y discursos, se expresan varios modelos estéticos, musicales y sensoriales y un sinfín de formas de acercarse al proceso ritual y de integrarse en él.

Todo ello da como resultado un riquísimo fenómeno sociocultural conformado por distintas funciones socio-simbólicas, significaciones y miradas que se han ido acumulando a lo largo de las diferentes fases históricas, que resulta extremadamente complejo de descifrar y que ni siquiera los propios cofrades-nativos dominan en su totalidad. Se trata de un extraordinario fenómeno que posee un inabarcable universo simbólico, de gran profundidad emocional, y que se halla incardinado en la memoria colectiva y en el contexto social, político, económico y religioso local.

En este artículo, hemos pretendido ofrecer una mirada sobre la celebración de la Semana Santa de Huelva a través de las lentes de la antropología, entendiéndola como una (auto)representación en clave simbólica de una ciudad en fiesta, ideal, evanescente, imaginada y deseada durante todo el año. Una ciudad mostrada y exhibida como una comunidad igualitaria -como communitas-, donde el anonimato participativo garantiza una igualdad simbólica casi total pero efímera, con fecha de caducidad, la del propio ritual. En contraposición con otras semanas santas que han sido invadidas por un turismo religioso y cofradiero en auge, hemos compuesto una etnografía sobre un ritual de carácter más privado, menos contaminado, desarrollado en una ciudad periférica donde los juegos de identidades locales no están inscritos en la 
cultura de la espectacularización (Jiménez de Madariga 2010), es decir, en el espectáculo de masas que se da en otras ciudades con semanas santas más famosas y que son vendidas como capital simbólico de consumo turístico.

En el juego de identidades locales que se desarrolla en la Semana Santa de Huelva, el propósito principal de los sujetos participantes en la dramatización es simplemente mostrarse, exhibirse ante la ciudad, que los vean; pero no que los vean y reconozcan individualmente, sino que vean a su cofradía, al resultado de su religioso trabajo grupal, producido en comunión con otros hermanos-militantes del grupo ritual al que se pertenece. Una cofradía sale a la calle para que la vean, para invadir la ciudad, para que participen en ella, de ella y con ella -y desde diferentes maneras de entender el hecho ritual-sus cofrades y el público que la observa en una conjunción místico-dramática y vivencial. Sale para ofrecer un discurso, un testimonio, una forma de hacer las cosas, una exhibición ritual por medio de un complejo lenguaje de símbolos, y para poner en juego unos iconos de identificación colectiva y una diversidad de acciones sensoriales y estéticas propias, vernáculas, producidas desde una lógica interna y "que establecen relaciones de sentido, resistencia y (auto)representación, desde la que expresan su singularidad los miembros y grupos que producen tales manifestaciones» (Periáñez Bolaño 2016: 29-30). Símbolos y manifestaciones que identifican a un conjunto de personas y grupos sociales unidos bajo los códigos de un ceremonial total.

\section{BIBLIOGRAFÍA CITADA}

Agudo Torrico, Juan y Celeste Jiménez de Madariaga. 2011. «Introducción», en Juan Agudo Torrico y Celeste Jiménez de Madariaga (coords.), Simposio Rituales y Cambios Sociales del XII Congreso de Antropología de la Federación de Asociaciones de Antropología del Estado Español. Lugares, Tiempos, Memorias. La Antropología ibérica en el siglo XXI: 1757-1769. León: Asociación de Antropología de Castilla y León Michael Kenny y FAAEE.

Augé, Marc. 2000. Los no lugares. Espacios del anonimato. Una antropología de la Sobremodernidad. Barcelona: Gedisa.

Bourdieu, Pierre. 2009. La eficacia simbólica. Religión y política. Buenos Aires: Biblos.

Box Varela, Zira. 2008. La fundación de un régimen. La construcción simbólica del franquismo. Tesis doctoral. Universidad Complutense de Madrid. Disponible en: <http://eprints. ucm.es/8572/>. Fecha de acceso: 26 jun. 2018.
Briones Gómez, Rafael. 1997. «Muerte y vida en la experiencia simbólica de la Semana Santa andaluza». Demófilo. Revista de Cultura tradicional de Andalucía 23: 193-214.

Cruces, Francisco y Ángel Díaz de Rada. 1995. «Celebraciones públicas en el Valle del Jerte». Etnografía española 9: 125135.

De la Campa Carmona, Ramón. 2004. «Las insignias», en Esther Fernández de Paz (dir.), Artes y Artesanías de la Semana Santa Andaluza. Vol. 9. Espacios y cortejos ceremoniales: 216-293. Sevilla: Ediciones Tartessos.

De Vicente Carmona, José Luis. 2010. El fenómeno religioso popular. Valores y carencias. Estudio de experiencias religiosas populares en Huelva a principios del siglo XXI. Tesis doctoral. Universidad de Huelva. Disponible en: <http:// rabida.uhu.es/dspace/bitstream/handle/10272/5367/ b15962775-1.pdf?sequence=2>. Fecha de acceso: 26 jun. 2018.

Delgado Ruiz, Manuel. 1999. El animal público. Hacia una antropología de los espacios urbanos. Barcelona: Anagrama.

Domene Verdú, José Fernando. 2017. «La función social e ideológica de las fiestas religiosas: identidad local, control social e instrumento de dominación». Revista de Dialectología y Tradiciones Populares 72(1): 171-197. doi: <https://doi. org/10.3989/rdtp.2017.01.007>.

Egizabal Suárez, Maribel. 2013. «Rituales en procesos de transformación del espacio público. Significado e influencias de algunas actuaciones en Bilbao la Vieja, San Francisco y Zabala». Zainak 36: 125-143.

Fernández Jurado, Jesús. 1997. «Consideraciones acerca de la reciente historia de la Semana Santa onubense». Demófilo. Revista de Cultura tradicional de Andalucía 23: 119-123.

Frazer, James George. 1944. La rama dorada. Magia y Religión. México: Fondo de Cultura Económica.

García García, José Luis. 1991. «Una introducción a las teorías actuales sobre el ritual», en José Luis García García et al., Rituales y proceso social: estudio comparativo en cinco zonas españolas: 9-14. Madrid: Instituto de Conservación y Restauración de Bienes Culturales.

Geertz, Clifford. 2003 [1973]. La interpretación de las culturas. Barcelona: Gedisa.

Goffman, Erving. 1961. Encounters. Two Studies in the Sociology of Interaction. Oxford: Penguin University Books.

Goffman, Erving. 2001. La presentación de la persona en la vida cotidiana. Buenos Aires: Amorrortu.

Goffman, Erving. 2016. "La diversión de los juegos». Apuntes de Investigación del CECYP 28: 12-67.

Gómez Lara, Manuel José y Jorge Jiménez Barrientos. 1997. «Fiesta, interpretaciones e ideología: la Semana Santa de Sevilla, drama ritual urbano». Demófilo. Revista de Cultura tradicional de Andalucía 23: 147-164.

González Isidoro, José. 2004. «Conformación de los cortejos procesionales a través de la historia», en Esther Fernández de Paz (dir.), Artes y Artesanías de la Semana Santa Anda- 
Iuza. Vol. 9. Espacios y cortejos ceremoniales: 16-69. Sevilla: Ediciones Tartessos.

Graeber, David. 2014. En deuda. Una historia alternativa de la economía. Barcelona: Ariel.

Guerrero Muñoz, Joaquín. 2012. "Comidas festivas y derroche en la Semana Santa y fiestas de primavera en la ciudad de Murcia», en Ángel B. Espina Barrio (ed.), Contención y derroche: Economía, Fiesta y Cultura en Iberoamérica: 604633. Salamanca: Instituto de Investigaciones Antropológicas de Castilla y León.

Hernández Burgos, Claudio. 2011. Granada Azul. La construcción de la "Cultura de la Victoria" en el primer franquismo. Granada: Comares.

Hobsbawn, Eric. 2002 [1983]. «Introducción: La invención de la tradición», en Eric Hobsbawn y Terence Ranger (eds.), La invención de la tradición: 7-21. Barcelona: Crítica.

Iborra Torregrosa, José. 2013. «Espacios urbanos y escenarios sagrados: la (des)territorialización de los procesos rituales en la Semana Santa». Zainak 36: 169-180.

Jiménez de Madariaga, Celeste. 2008. "Devotos y espectadores. Rezar y hacer turismo», en Elizabeth Díaz Brenis y Javier Hernández (coords.), Patrimonio Cultural, Turismo y Religión: 147-161. México: Escuela Nacional de Antropología.

Jiménez de Madariaga, Celeste. 2010. «Turismo y espectacularización de los rituales festivo-religiosos», en XIII Congreso Latinoamericano sobre Religión y Etnicidad. Diálogo, ruptura y mediación en contextos religiosos: 1-16. Granada: Universidad de Granada y Asociación Latinoamericana de Estudios de Religión.

Lefebvre, Henri. 1978. El derecho a la ciudad. Barcelona: Ediciones Península.

Lévi-Strauss, Claude. 1968. Antropología estructural. Buenos Aires: Eudeba.

Machuca, José Félix. 2013. Swing María. Sevilla: ABC Biblioteca Palabras de Pasión.

Mancha Castro, José Carlos. 2017. "Cofradías y poderes políticos. Una aproximación a las hermandades de Semana Santa en la Huelva del primer franquismo». Revista Andaluza de Antropología 13: 140-163. doi: <https://doi. org/10.12795/raa.2017.13.06>

Mancha Castro, José Carlos. 2018. «La Semana Santa y la recatolización de Huelva. Un acercamiento a la construcción simbólica del franquismo de posguerra». Pasado y Memoria. Revista de Historia Contemporánea 17: 413-452. doi: <https://doi.org/10.14198/pasado2018.17.15>.

Martínez Kleiser, Luis. 2003 [1924]. La Semana Santa de SeviIla. Sevilla: Espuela de Plata.

Martínez Velasco, Julio. 2013. La Semana Santa de Sevilla de ayer a hoy. Sevilla: ABC Biblioteca Palabras de Pasión.

Mauss, Marcel. 1979 [1971]. Sociología y Antropología. Madrid: Editorial Tecnos.
Moreno Navarro, Isidoro. 1999 [1974]. Las Hermandades andaluzas: una aproximación desde la Antropología. Sevilla: Secretariado de publicaciones Universidad de Sevilla.

Moreno Navarro, Isidoro. 2006a. "La Semana Santa de Huelva», en Esther Fernández de Paz (dir.), Artes y Artesanías de la Semana Santa Andaluza. Vol. 1. La Semana Santa como Patrimonio Cultural de Andalucía: 252-289. Sevilla: Ediciones Tartessos.

Moreno Navarro, Isidoro. 2006b [1982]. La Semana Santa de Sevilla. Conformación, mixtificación y significaciones. Sevilla: Biblioteca de Temas Sevillanos.

Moreno Navarro, Isidoro y Juan Agudo Torrico. 2012. «Las fiestas andaluzas», en Isidoro Moreno Navarro y Juan Agudo Torrico (coords.), Expresiones culturales andaluzas: 165218. Sevilla: Aconcagua libros.

Periáñez Bolaño, Iván. 2016. «Ser y sentir flamenco: descolonizando la estética moderno colonial desde los bordes». Revista Andaluza de Antropología 10: 29-53. Disponible en: <http://www.revistaandaluzadeantropologia.org/uploads/ raa/n10/perianez.pdf>. Fecha de acceso: 26 jun. 2018.

Richards, Michael. 2010. «Presentando armas al Santísimo Sacramento: Guerra Civil y Semana Santa en la ciudad de Málaga, 1936-1939», en Chris Ealham y Michael Richards (eds.), España fragmentada. Historia cultural y Guerra Civil española: 253-286. Granada: Comares.

Rina Simón, César. 2015. «La construcción de los imaginarios franquistas y la religiosidad "popular", 1931-1945». Pasado y Memoria. Revista de Historia Contemporánea 14: 179-196. doi: <https://doi.org/10.14198/PASADO2015.14.07>.

Rina Simón, César. 2016. «Rituales de pasión, muerte y resurección. La religiosidad popular y la legitimidad sagrada en el franquismo», en Francisco Cobo Romero, Claudio Hernández Burgos y Miguel Ángel del Arco Blanco (eds.), Fascismo y modernismo: política y cultura en la Europa entreguerras (1918-1945): 171-184. Granada: Comares.

Rina Simón, César. 2017. «Fascismo, nacionalcatolicismo y religiosidad popular. Combates por la significación de la dictadura (1936-1940)». Historia y Política. Ideas, procesos y movimientos sociales 37: 241-266. doi: <https://doi. org/10.18042/hp.37.09>.

Rodríguez Becerra, Salvador. 1985. Las fiestas de Andalucía. Sevilla: Editoriales Andaluzas Unidas.

Rodríguez Becerra, Salvador. 2006. La religión de los andaluces. Málaga: Sarriá.

Rodríguez Mateos, Joaquín. 1998. La ciudad recreada. Estructura, Valores y Símbolos de las Hermandades y Cofradías de Sevilla. Sevilla: Diputación de Sevilla.

Rufino, César y Nieves Grosso. 2014. «El primer 'nazareno'». Revista Más Pasión 7 85: 24-28.

Sánchez Herrero, José. 2003. La Semana Santa de Sevilla. Madrid: Sílex.

Schechner, Richard. 2000. Performance. Teoría y prácticas interculturales. Buenos Aires: Libros del Rojas y Universidad de Buenos Aires. 
Sugrañes Gómez, Eduardo Jesús. 1988. La Unión de Cofradías de Huelva (Recorrido histórico por el movimiento asociativo de las hermandades de penitencia). Huelva: Imprenta Huelva llustrada.

Sugrañes Gómez, Eduardo Jesús. 1994. Estación de penitencia y Carrera Oficial en Huelva. Huelva: Asociación de Industrias Químicas y Básicas de Huelva.

Sugrañes Gómez, Eduardo Jesús y Pedro Gil-Mazo. 1991. Los penitentes de Huelva. Huelva: CECA.
Turner, Victor. 1980. La selva de los símbolos. Madrid: Siglo $\mathrm{XXI}$.

Turner, Victor. 1988. El proceso ritual. Estructura y antiestructura. Madrid: Taurus.

Turner, Victor. 2002. "La antropología del performance», en Victor Turner e Ingrid Geist (comps.), Antropología del ritual: 103-144. México: Instituto Nacional de Antropología e Historia.

Van Gennep, Arnold. 2008 [1909]. Los ritos de paso. Madrid: Alianza. 